\title{
The Passive Margin of the U.S.A.
}

\author{
by Robert E. Sheridan
}

The east coast of the U.S.A. is the archetypal passive margin. Draped over the basement are sedimentary rocks of Middle Jurassic to Holocene age, thickest in five major basins that dominate the structure. The U.S. Atlantic margin broke apart during the Middle Jurassic at roughly the same time as the Gulf of Mexico. Both areas underwent a shift in major spreading center a few million years after break-up, leaving an extinct spreading center and oceanic crust north of Florida and an unusually wide transitional crust under the Blake-Bahamas region.

\section{Introduction}

The Atlantic continental margin from Maine to Florida is the classic passive margin. Formed by the rifting, break-up, and drift of North America and Africa, the thick Mesozoic-Cenozoic sedimentary cover of the coastal plain, continental shelf, slope and rise straddles three distinct types of basement: continental, transitional, and oceanic. The continental crust under the inner shelf, coastal plain and to the landward is marked by exposed and buried rift basins formed by asymmetric half grabens (Fig. 1). The transitional crust under the outer continental shelf and Blake Plateau is deeply subsided and underlies five major sedimentary basins: Georges Bank Basin, Baltimore Canyon Trough, Carolina Trough, Blake Plateau Basin, South Florida-Bahamas Basin. The boundary between the transitional crust and the true oceanic crust is marked by the linear East Coast magnetic anomaly (ECMA) north of Florida, and farther east by the Blake Spur magnetic anomaly (BSMA) in the Blake-Bahamas region. The thick sediments of the continental rise lie directly on oceanic crust (Sheridan et al., 1979; Klitgord and Hutchinson, 1985; Grow et al., 1983).

\section{Mesozoic Rift Stage Basins}

These narrow, linear basins generally parallel the prevailing northeast-southwest strike of the Appalachian orogen basement (Fig. 1). Ages of sediments in the rift basins range from Triassic to Middle Jurassic (Manspeizer, 1985) and reach up to $10 \mathrm{~km}$ in thickness. The structure of the basins is dominantly one of a half graben with a major listric normal fault as a border fault. As Figures 2 and 3 show, offshore these rift basin structures are well observed seismically (Klitgord and Hutchinson, 1985; Grow et al., 1983). In some cases the border faults are on the northwest, while in others they are on the southeast.

In the exposed basins, sedimentary deposits are generally fluvial and lacustrine in nature (Manspeizer, 1985). Fanglomerates grade basinward from the border fault margin into fine-grained lacustrine organic-rich black shales and argillites. The lake deposits are interlayered with fluvial sandstones and shales. Recent seismic profiles across the rift basins onshore (Rateliffe et al., 1986) and offshore (Hutchinson et al., 1986) reveal that the border faults are dipping at low angles (about $30^{\circ}$ ) and apparently reoccupy deep-penetrating Paleozoic thrust faults. Consequently, the Mesozoic rift basins are oriented and positioned by the pre-existing basement structure of the Appalachian orogen (see Rodgers, this issue).

Offshore, the syn-rift structures of the half grabens and the enclosed tilted sediments are truncated by a major discontinuity with the overlying through-going reflectors of the onlapping drift stage sequences (Fig. 2, 3 and 4). This discontinuity is often a hiatus called the break-up (Falvey, 1974) or post-rift unconformity (PRU; Grow et al., 1983). Beneath it the truncated and tilted reflectors of the syn-rift sedimentary sequences are revealed seismically.

Apparently astride the boundary between transitional and oceanic crust under the ECMA (Figs. 2, 3), thick wedges of seaward-dipping reflectors commonly occur (Klitgord and Hutchinson, 1985). These have also been found on other passive margins (Mutter, 1985) and have been drilled (Roberts et al., 1984). They are interpreted as thick wedges of intercalated sedimentary rocks and basalts formed at the time of breakup (White et al., 1987).

\section{Mesozoic-Cenozoic Drift Stage}

After break-up in Middle Jurassic time, the newly formed Atlantic Ocean invaded the U.S. eastern margin. As the basement subsided with thermal cooling of the lithosphere, shallow marine sedimentary rocks progressively onlapped the PRU (Klitgord and Hutchinson, 1985; Grow et al., 1983; Dillon et al., 1979; Sheridan et al., 1981). Where the earliest drift stage and latest rift stage rocks were drilled on the Atlantic continental margin, such as in Georges Bank Basin (Fig. 2; Poag, 1982) and the Bahamas (Fig. 4; Sheridan et al., 1981), the earliest onlapping sediments were interbedded limestone, dolomite and anhydrite. These evaporites and carbonates were deposited in warm shallow seas overlying either the PRU or a late rift stage halite deposit. The salt layer just beneath these onlapping beds is limited to several zones of salt diapirs in the Baltimore Canyon Trough and the Carolina Trough. Salt has been drilled beneath the Georges Bank Basin (Grow et al., 1983; Poag, 1982).

All along this margin, the Middle Jurassic to earliest Cretaceous was a time of carbonate deposition that formed a $\mathrm{pro}^{-}$ nounced paleoshelf edge (Fig. 2, 3, and 4). The carbonate deposits formed a formidable, seismically identifiable structure along this edge from Georges Bank to the Bahamas. This carbonate bank was eroded periodically from the Jurassic or earlier, so that steep escarpments are now buried under the continental slope (Sheridan et al., 1981; Mattick et al., 1978). Apparently, the continental drift of the North American plate carried the U.S. Atlantic margin progressively north of $30^{\circ} \mathrm{N}$ latitude from earliest Cretaceous time. Thus, the carbonate banks terminated earlier on the Georges Bank Basin (Neocomian) and later on the Blake Plateau Basin, (Cenomanian), but still exist in the Bahamas (Jansa, 1981).

As sea-floor spreading continued and North America moved away from the hot spreading center, the thermal cooling of the lithosphere caused continental subsidence. By latest Jurassic time, the sediment load on the cooling lithosphere caused flexural downbending of the adjacent unthinned continental crust to form the coastal plain landward of the hinge zone (Fig. 2, 3; Watts, 1981). Continued cooling, subsidence, and flexture increased the width and thickness of the coastal plain wedge.

Mechanical stretching by viscous processes, crustal thinning by brittle, listric normal fault rotations, and intrusion and underplating of the transitional crust all contributed to drastic subsidence seaward of the hinge zone (Watts, 1981; White et al., 1987). The subsidence varied along strike to 


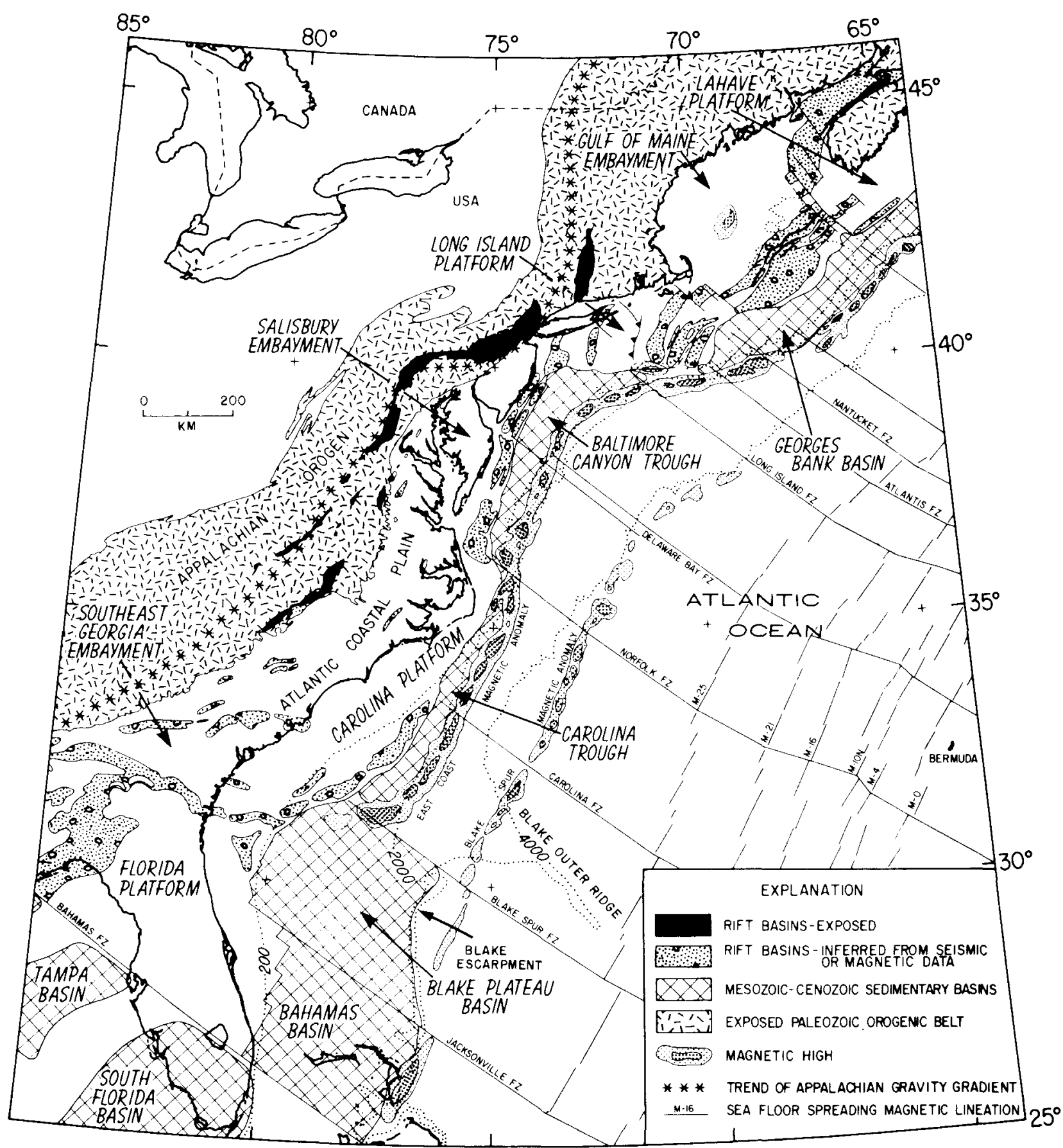

Figure 1: Structural and geophysical features of the U.S. Atlantic continental margin. From Hutchinson and Klitgord (in press)

produce five distinct and separated depositional basins. The Georges Bank Basin, which is the shallowest of the basins off the U.S.A., subsided some 6-7 km (Fig. 2). This contrasts with the deeper basin of the Baltimore Canyon Trough that reaches $12-14 \mathrm{~km}$. The shallow, positive basement of the Long Island Platform (Fig. 1) separates these two major basins. Similarly the Carolina and Florida Platforms separate the Baltimore Canyon and Carolina Troughs and the Blake Plateau and South Florida-Bahamas Basins, respectively.

The isolation of these basins and their variations in depth and width relate to pre-existing weaknesses and rheological behaviour of the North American basement. The Paleozoic
Appalachian orogen was marked by major suture zones and promontories and re-entrants (see Rodgers, this issue). For example, the Long Island Platform forms a major offset in the modern passive margin that mimies the major curvature of the Appalachian structures between the New York promontory and the Pennsylvania re-entrant. Similarly the Florida Platform and the Blake Plateau are southeast of the Appalachian sutures where they swing westward across Georgia (Fig. 1), and therefore originated on African basement with perhaps different rheological behaviour (Sawyer, 1985). These dominant offsets in Paleozoic basement are inherited in the Mesozoic passive margin, and eventually in the major fracture zone offsets in the modern Atlantic.

Indeed, these basement rheological differences controlled by Paleozoic structures had even more subtle influences landward of the hinge line. There, the flexing lithosphere varied along strike in subsidence so that slightly deeper $(2-3 \mathrm{~km})$ 


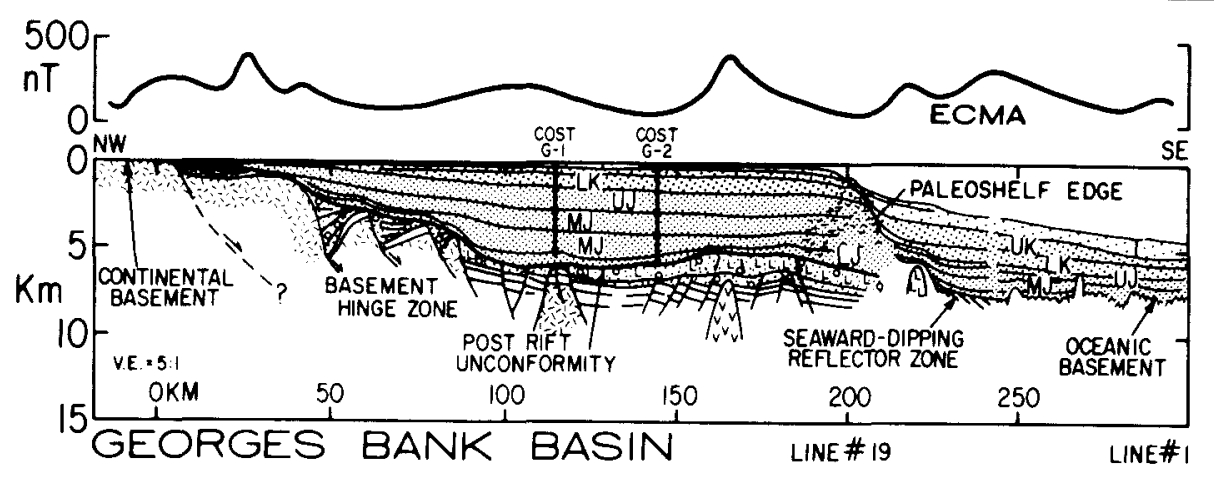

${ }^{n T}{ }_{0}^{500}[$

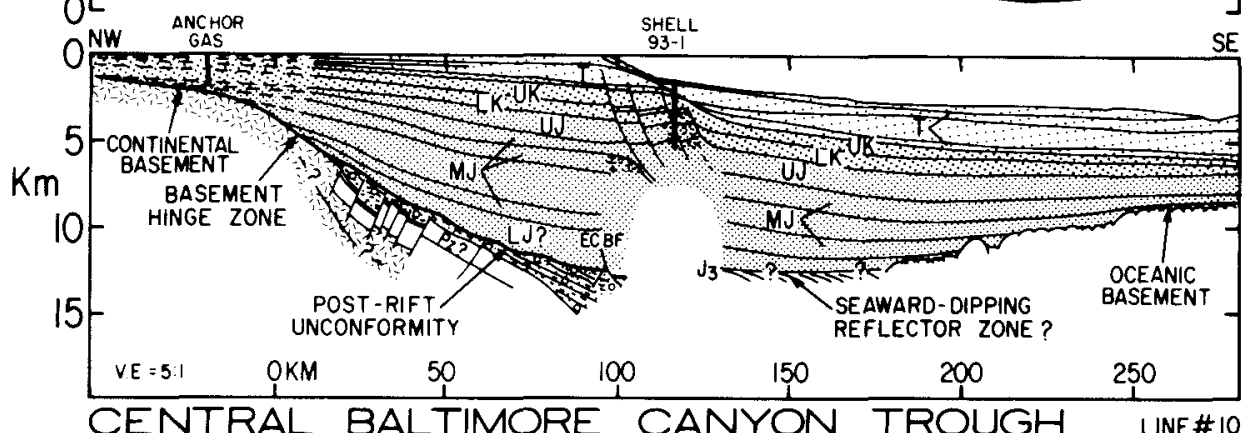

depressions of the basement occurred, as in the Southeast Georgia and Salisbury Embayments (Fig. 1). Magnetic anomalies associated with Paleozoic terrane sutures bound the centers of these embayments.

Major Basins of the Drift Stage

In the Georges Bank Basin, the shallowest of the basins, the entire drift stage sequence has been penetrated by the Continental offshore Stratigraphic Test (COST) Gl and G2 wells (Fig. 2; Poag, 1982). These sediments reach $6-7 \mathrm{~km}$, but there are well defined syn-rift and pre-rift sedimentary basins below these depths. Jurassic salt has been penetrated in a COST well and appears as a seismic layer across the base of the basin. Few piercing diapirs are found in the basin, but more diapirs form a ridge province under the continental slope.

Jurassic through lowermost Cretaceous carbonates and evaporites cover most of the basin and pass seaward into a major carbonate platform edge under the continental slope.

Figure 2: Cross-sections of the U.S. passive margin based on multi-channel seismic reflection profiles (from Klitgord and Hutchinson, 1985). Magnetic profiles are shown above each section. ECBF - East Coast Boundary Fault.

Figure 3: Interpreted cross-sections across the Carolina Trough (from Grow and others, 1983), and the Blake Plateau (from Dillon et al., 1979).
Smaller isolated carbonate banks are found in the interior of the basin as well. During the Late Cretaceous and Tertiary time, siliclastic deposition dominated to build the shelf to its present form. Quaternary deposition of thick glacial sands, gravels, and tills topped the shelf in this area to form the Georges Bank, which was further defined by the glacial erosion of adjacent Gulf of Maine and Northeast Channel.

In the outer part of the Baltimore Canyon Trough the thickness of drift stage sediments reaches $12-14 \mathrm{~km}$, and syn-rift sediments and dipping reflector wedges could reach greater
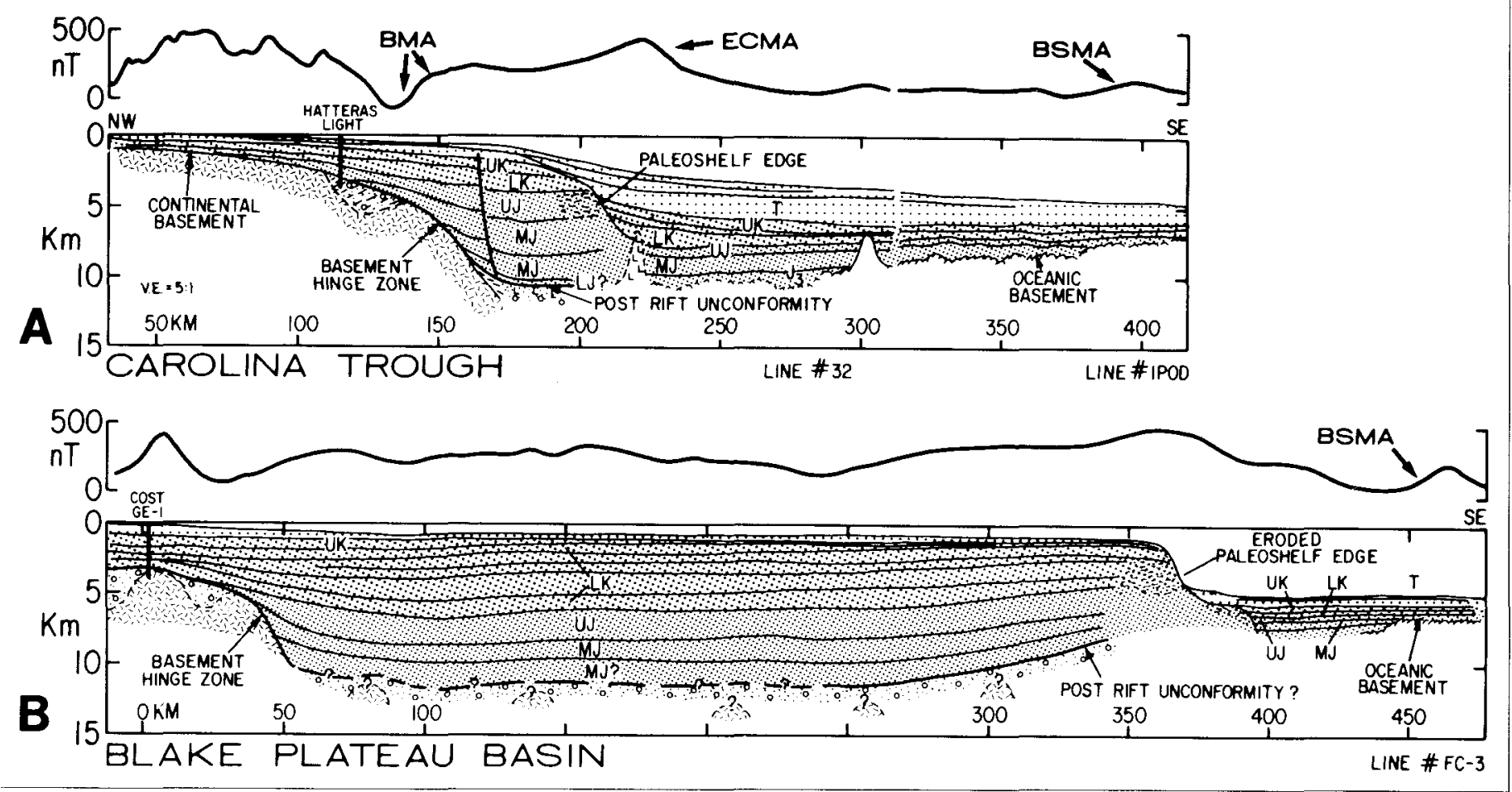
thicknesses below that (Fig. 2; Grow et al., 1983). Jurassic salt at the base of the drift stage sequence has formed salt pillows and diapirs that have penetrated to within $5 \mathrm{~km}$ of the surface. Jurassic through lowermost Cretaceous carbonates cover the lower part of the basin and prograde eastward to form a prominent carbonate platform edge. Erosion along this edge created a steep escarpment now buried by Upper Cretaceous marine sediments. Near the edge of the continental shelf, there are a number of deeppenetrating listric growth faults, motion along which has caused rotation of the older carbonate platform edge. This created a large structural closure in porous carbonate rocks, which was tested in recent petroleum exploration wells by Shell (Fig. 2).

In the Late Cretaceous and Early Tertiary, siliciclastic deposits draped the carbonate platform edge. Through Early Tertiary, the continental shelf deepened as sediment influx slackened with continued subsidence; the starved margin sedimentation was dominated by chemical deposition of glauconite and diatomite (Olsson, 1978). In the Late Tertiary, the deep shelf was filled in with prograding sequences of sands and gravels to build the shelf edge out to its present position. Meanwhile, canyon cutting and other deep marine erosional processes sculptured the continental slope and upper continental rise.
After Cenomanian time, the continued subsidence of the plateau with the beginning of the Gulf Stream led to its starvation and erosion causing the deepening of the plateau to greater than $1000 \mathrm{~m}$. In the same interval, several processes, including mass wasting, chemical and biological corrosion and current erosion, caused several $\mathrm{km}$ of retreat of the Blake Escarpment (Paull and Dillon, 1980).

In addition to its great width, the Blake Plateau is different from those to the north in that the ECMA dies out just to the north. Near the seaward edge of the Blake Plateau, the BSMA is thought to mark a basement ridge structure formed by extrusions along a new spreading center that shifted from its former location to leave an extinct center in the ECM A-BSMA corridor (Fig. 1). Consequently, the broad Blake Plateau Basin has no equivalent on the African side of the Atlantic.

Seismic data indicate that the South Florida-Bahamas Basin (Fig. 4) contains thicknesses from 5 to $12 \mathrm{~km}$ of Jurassic to Holocene sedimentary rocks (Sheridan et al., 1966; 1981). The few wells in the Bahamas that have penetrated these rocks, show that they are consistently shallow water limestones, dolomites and evaporites, and deep-water limestones. Seismic reflection profiles reveal a faulted, rifted basement under the western Bahamas extending from

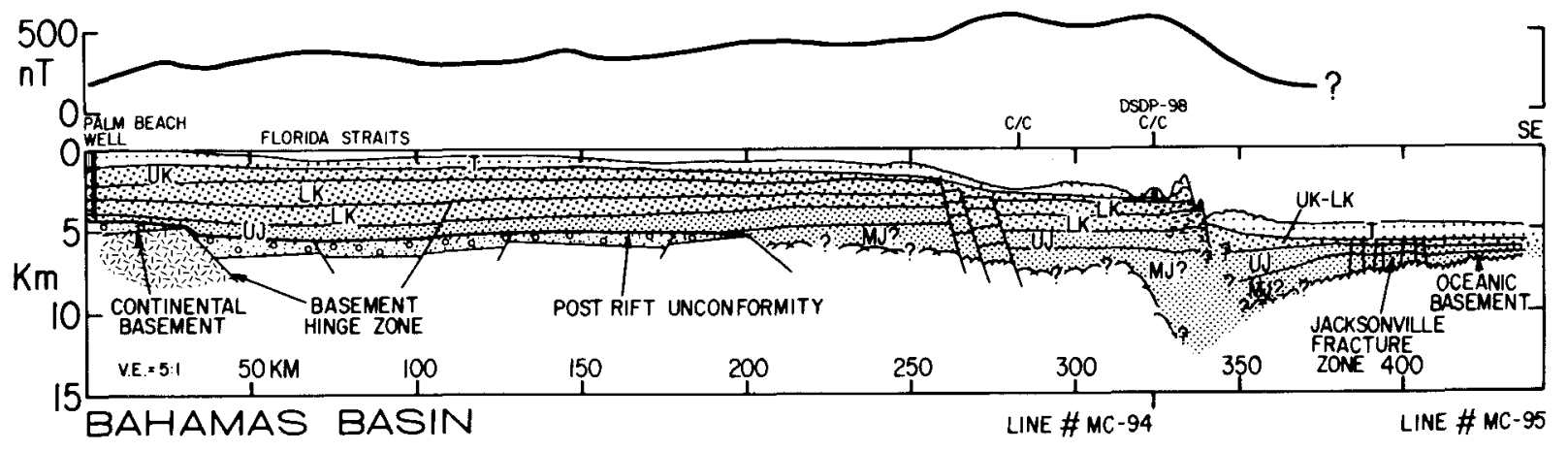

Figure 4: Interpreted section across the Bahamas basin (from sheridan et al., 1981).

The Carolina Trough is one of the narrowest basins of the U.S. passive margin (Fig. 3), but it reaches $11-12 \mathrm{~km}$ in thickness (Grow et al., 1983). At the base of the section, Jurassic salt has been identified seismically, this layer being a source for a ridge of diapirs under the continental slope. The Jurassic to lowermost Cretaceous carbonate platform forms a pronounced paleoshelf edge. One of the most welldeveloped growth faults of the margin occurs under the outer shelf of the Carolinas, and can be traced for more than $100 \mathrm{~km}$ along strike. Apparently, the movement of the flowing salt beneath the brittle carbonate platform has allowed slippage along the fault and rotation of the entire shelf edge block as one piece. Accordingly the diapir ridge along the continental slope is one of the best developed along the U.S. passive margin.

The Blake Plateau Basin is one of the widest along the whole margin, reaching nearly $300 \mathrm{~km}$, compared to $100-150 \mathrm{~km}$ for the basins to the north. Sedimentary rocks reach to depths of $12 \mathrm{~km}$ (Fig. 3). Jurassic to Cretaceous carbonates persist over the plateau, and Lower and Upper Cretaceous limestones and dolomites have been dredged and sampled by submersibles along the Blake Escarpment (Sheridan et al., 1966; Dillon et al., 1985). Seismic data do not read the basement very well beneath the carbonates, but the transitional crust must be heavily intruded with basaltic rocks to account for the crustal thickness and subsidence (Sheridan et al., 1981; Sawyer, 1985).
Florida to a point in the Bahamas where the BSMA projects inland (Sheridan et al., 1981). Southeast of this point the basement is a hummocky reflecting surface interpreted as oceanic crust.

Upper Cretaceous reflection horizons appear offset by faults that might extend into Tertiary rocks. These relatively young faults are attributed to stresses related to effects of the Cuban Orogeny during the early Tertiary. Faults and folds were known to exist in the southern Bahamas just north of Cuba, and faults as far north as Little Bahama Bank have now been found (Fig. 4). This faulting in Late Cretaceous and Tertiary time apparently segmented what was once a broader, megabank beneath the Florida-Blake-Bahamas area. Isolated banks then developed, surrounded by the deeper channels through which the Gulf Stream and Antilles currents flowed.

\section{Plate Reconstructions and Paleogeography}

Recent DSDP results at Site 534 east of Florida (Fig. 5) yield a more precise age for the breakup of North America and Africa, and evidence on the paleogeography of the earliest Atlantic Ocean (Sheridan et al., 1983). The age of the basement and projections of constant spreading rates to BSMA and ECMA date these anomalies as earliest Callovian and Bathonian (Middle Jurassic), respectively. These are now younger than previously thought and similar to the ages interpreted for the breakup of the Gulf of Mexico and Yucatan Caribbean margin. This simplifies the breakup history of these three ocean margins. 


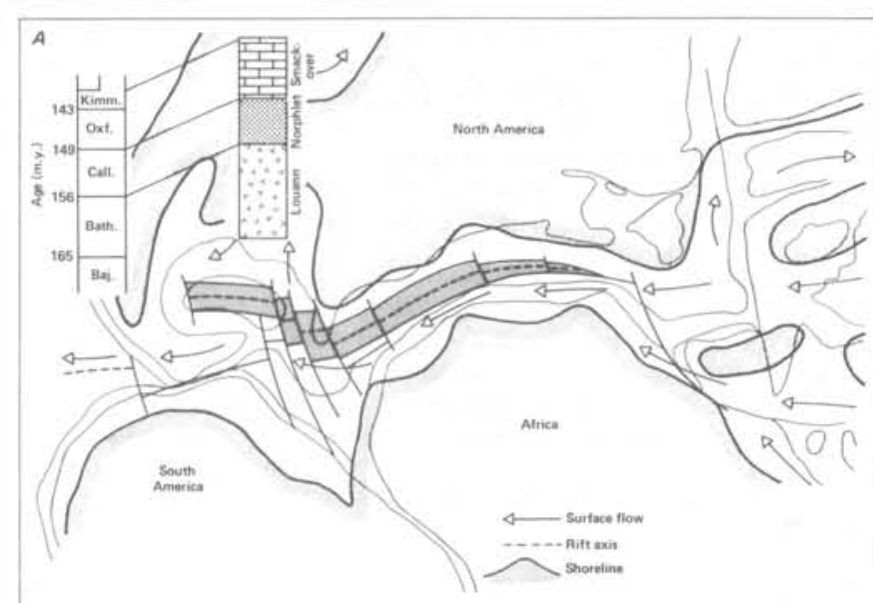

The U.S. Atlantic margin and the Gulf of Mexico began to break apart during Bathonian time, with the creation of a small strip of oceanic crust that formed the ECMA. Just a few million years later, in earliest Callovian time, a spreading center shift occurred to create the BSMA on the Atlantic margin and to begin the breakup of the Yucatan Caribbean margin (Fig. 5). With the shift to the BSMA, the extinct spreading center and older oceanic crusts in the ECMA-BSMA corridor off the U.S. margin and the Gulf of Mexico were left isolated. This contributed to the asymmetry that resulted in the Jurassic magnetic quiet zone being wider off the U.S. margin and narrower off Africa. In short, this extinct spreading center was attached to the North American plate and drifted away from Africa.

Paleoenvironmental data from Site 534 (Sheridan et al., 1983) and other data in the circum Atlantic region for the Jurassic (Manspeizer, 1985) indicate that the early Atlantic Ocean was more latitudinal and equatorial in nature. Consequently, easterly trade winds and currents dominated at the surface. With the breakup and initiation of the Jurassic Caribbean, complicated Tethyan circulation to the Pacific occurred, and bottom currents began to flow, perhaps driven by salinity (Sheridan et al., 1983). Several lines of evidence suggest bottom current flow from the African margin at Site 534 during the Jurassic (Fig. 5). The U.S. passive margin then moved north of $30^{\circ} \mathrm{N}$ latitude, where westerly currents dominated with evolution of the Gulf Stream eirculation. This fundamental change in paleoenvironment occurred around the time of the Middle Cretaceous.

Dr. R. Sheridan is Professor of Geology and Geophysics, Department of Geological Sciences, Rutgers University, (New Brunswick, NJ 08903 , U.S.A.). He specializes in the study of the geology and geophysics of the North American continental margin. He is Past Chairman of the JOIDES Passive Margin Panel and former Co-chief Scientist of two DSDP cruises on the Atlantic Margin.

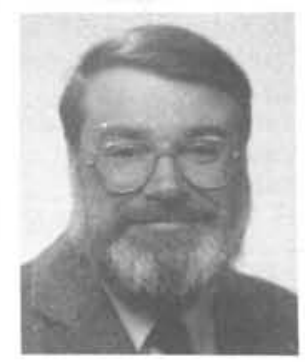
mia-Oxfordian (Late Jurassic), the age of magnetic anomaly 26 (from Sheridan et al., 1983).

References

Dillon, W.P., Paull, C.K., Dahl, A.G. and Patterson, W.C. 1979. Structure of the continental margin near the cosT No. GE-1 drill site from a common depth-point seismiereflection proflle. In: Scholle, P.A. (ed.), Geologic Studies of the COST GE-1 well, United States South-Atlantic Outer Continental Shelf Area. U.S. Geological Survey Circular 800, p. 97-107.

Dillon, W.P., Paull, C.K. and Gilbert, L.E., 1985. History of the Atlantic continental margin off Florida: The Blake Plateau basin. In: Pong, C.W. (ed.), Geologic Evolution of the United States Attantic Margin. Van Nostrand Reinhold, New York, p. 189-215.

Palvey, D.A., 1974. The development of continental margins in plate tectonic theory. Australian Petroleum Exploration Association Journal, v. 14, no. 1, p. 95-106.

Grow, J.A., Hutehinson, D.R., Klitgord, K.D., Dillon, W.P. and Schlee, J.S., 1983, Representative multichannel seismic profiles over the U.S. Atlantic margin. In: Bally, A.W. (ed.), Seismic Expression of Structural Styles; A Picture and Work Atlas, v. 2 . American Association of Petroleum Ceologists Studies in Geology, no, 15, v. 2, p. 2.2.3-1 2.2.3-19.

Hutehinson, D.R., Klitgord, K.D. and Detrick, R.S., 1986. Rift basins of the Long lsland Platform. Geological Society of America Bulletin, v. 97, no. 6, p. 688-702.

Hutehinson, D.R. and Klitgord, K.D., in press. Deep structure of the rift basins from the continental margin around New England. U.S. Geological Survey Bulletin 2776.

Jansa, L.F., 1981. Mesozoic carbonate platforms and banks of the eastern North American margin. Marine Geology, v. 44, no 1-2, p. 97-117.

Klitgord, K.D., and Hutehinson, D.R., 1985. Distribution and geophysical signatures of early Mesozoic rift basin beneath the U.S. Atlantic continental margin. In: Robinson,
G.R., Jr, and Froelich, A.J., The Eariy Mesozoic Basins of the Eastern United States. U.S. Geological Survey Circular 946, p. 45-61.

Manspeizer, W., 1985. Early Mesozoic history of the Atlantic passive margin. In: Poag, C.W. (ed.), Geologic Evolution of the United States Atlantic Margin. Van Nostrand Reinhold, New York, p. 1-23.

Mattick, R.E., Girard, O.W., Jr., Seholle, P.A. and Grow, J.A. 1978. Petroleum potential of the U.S. Atlantic slope, J.A., 1978. Petroleum potential of the U.S. Atantic slope, Geologists Bulletin, v. 62 , no. 4, p. 592-608.

Mutter, J.C., 1985. Seaward dipping reflectors and the continent-ocean boundary at passive continental margins Tectonophysics, v. 114, no. 1-4, p. 117-131.

Olsson, R.K. et al., 1978. Summary of lithostratigraphy and biostratigraphy of Atlantic coastal plain (northern part). In: Initial Reports of the Deep Sea Drilling Project, v. 44 U.S. Governm
p. $941-947$.

Paull, C.K. and Dillon, W.P., 1980. Erosional origin of the Blake Escarpment: An alternative hypothesis. Geology, v. 8 , no. 11 , p. 538-542.

Poag, C.W., 1982. Stratigraphic reference section for Georges Bank Basin; depositional model for New England Passive Marrin. Ameriean Assoeiation of Petroleum Geologists Bulletin, v. 66, no. 8, p. 1021-1041.

Rateliffe, N.M., Burton, W.C., D'Angelo, R.M. and Costain, J.K., 1986. Low-angle extensional faulting, reactivated mylonites, and seismic reflection geometry of the Newark Basin margin in eastern Pennsylvania. Geology, v. 14, no. 9 p. $766-770$.

Roberts, D.G., et al., 1984. Late Paleocene-Eocene volcanic events in the northern North Atlantic Ocean. In: Initial Reports of the Deep Sea Drilling Project, v. 81. U.S. Government Printing Office, Washington, D.C., p.913-923.
Sawyer, D.S., 1985. Total tectonic subsidence: A parameter for distinguishing crustal type at the U.S. Atlantic continental margin. Journal of Geophysical Research, v 90, no. 9, p. 7751-7769.

Sheridan, R.E. et al., 1983. Phenomena of puisation tectonic related to the breakup of the eastern North America continental margin. In: Initial Reports of Deep Sea Drilling Project, v. 76. U.S. Government Printing Office, Washington, D.C., p. 897-909.

Sheridan, R.E., Drake, C.L., Nate, J.E. and Hennion, J., 1966. Seismic-refraction study of the continental mangin 1966. Seismic-refraction study or the continental mangin Geologists Bulletin, v. 50, no. 9, p. 1972-1991.

Sheridan, R.E., Grow, J.A., Behrendt, J.C. and Bayer, K.C. 1979. Seismic refraction study of the continental edge of the eastern United States. Tectonophysies, v. 59, no. 1-4, p. 1-26.

Sheridan, R.E., Crosby, J.T., Bryan, G.M. and Stoffa, P.L., 1981. Stratigraphy and structure of southern Blake Plateau, northern Florida Straits, and northern Bahame platform from multichannel seismic reflection data. American Association of Petroleum Geologists Bulletin, y, 65, no, 12 p. 2571-2593.

Watts, A.B., 1981. The U.S. Atlantic continental margin: Subsidence history, erustal structure and thermal evolution. In: Bally, A.W. et al. (eds.), Geology of Passive Continental Margins: History, Strueture and Sedimentological Record (with special emphasis on the Atlantic Margin). American Association of Petroleum Geologists, Continuing Edueation Course Note Series 19, Chapter 2, p. 1-75.

White, R.S. et al., 1987, Hatton Bank (Northwest U.K.) continental margin structure. Geophysical Journal of the Royal Astronomical Society, v. 89, no. 1, p. 265-272. 